\title{
A Systematic Review: Competence of Teachers in Implementation of Culturally Responsive Pedagogy
}

\author{
Yew Pei Jia, Nurfaradilla Mohamad Nasri \\ Faculty of Education, Universiti Kebangsaan Malaysia, Selangor, Malaysia \\ Email: yewpeijia0216@gmail.com,nurfaradilla@ukm.edu.my
}

How to cite this paper: Jia, Y. P., \& Nasri, N. M. (2019). A Systematic Review: Competence of Teachers in Implementation of Culturally Responsive Pedagogy. Creative Education, 10, 3118-3130. https://doi.org/10.4236/ce.2019.1012236

Received: October 21, 2019

Accepted: November 26, 2019

Published: November 29, 2019

Copyright ( 2019 by author(s) and Scientific Research Publishing Inc. This work is licensed under the Creative Commons Attribution International License (CC BY 4.0).

http://creativecommons.org/licenses/by/4.0/

Open Access

\begin{abstract}
Malaysia is a country with multi-race, which comprised of Malay, Chinese, Indian and so on. When it comes to education, all students from these different cultural backgrounds will be a group in the same classroom to learn and grow together. Therefore, to ensure that the pedagogy delivered is relevant to the students, a culturally responsive pedagogy should be practiced by the teachers. Culturally responsive pedagogy is a student-centered teaching approach that is sensitive to students' cultural orientations, including students' cultural references and getting to know students' cultural backgrounds as well as students' previous experiences which would affect their learning. Teachers, therefore are encouraged to learn and to apply culturally responsive pedagogy in teaching to ensure that students' learning is responsive to their respective culture background. Objectives are as below, 1) Are the teachers competent in the implementation of culturally responsive pedagogy? 2) What hinders the implementation of culturally responsive pedagogy? On that note, a systematic literature review was carried out to gather evidence from the previous empirical studies on issues related to culturally responsive pedagogy. A total number of 15 articles were identified that met the study's objectives. The findings through systematic review show that teachers have to improve their knowledge, understanding and self-efficacy towards culturally responsive pedagogy. Furthermore, the study found out that pedagogy that teachers used, curriculum and assessment are the issues in the implementation of culturally responsive pedagogy. Pre-service teachers should be given more training by using culturally responsive pedagogy while doing a practicum in the actual field.
\end{abstract}

\section{Keywords}

Systematic Review, Culturally Responsive Pedagogy, Teachers' Competency, Malay Language, Students' Background 


\section{Introduction}

Culture is central to how all learning takes place (Gay, 2010). Culturally responsive pedagogy is a student-center approach in teaching that includes cultural references and recognizes the importance of students' cultural backgrounds and experiences in all aspects of learning, (Ladson-Billings, 1995). When planning for instruction, educators must be aware of their students' readiness to learn, their interests, and their learning profile, which includes learner preferences, strengths, and challenges, (Laura \& Christine, 2018). In a simpler word, culturally responsive pedagogy refers to a technique of teaching by teachers who are committed to cultural competence, establish high expectations, and position themselves as both facilitators and learners. In other words, a culturally responsive teacher will be designing all the lesson plans by considering students' cultural background. For examples, in designing Malay language lesson plans for Chinese students, Malaysian teachers have to consider students' competencies level of and readiness for the Malay language. Teachers have to put more effort in teaching students because Malay language is not the mother-tongue for Chinese students despite being a national language in Malaysia. Culturally responsive pedagogy has the potential to be an effective teaching approach for teaching students of multi-racial. However, less study was done in Asian, particularly in Malaysia. Culturally responsive pedagogy is suitable to be carried out in the class teaching since there are students with different cultural backgrounds. Therefore, teachers must be knowledgeable on what is culturally responsive pedagogy, to understand the impact of culture on teaching and learning, and to be able to implement culturally responsive pedagogy efficiently.

\subsection{Characteristics of Culturally Responsive Teacher}

As culturally responsive teachers, teachers must understand all the culture background of their students. (Laura \& Christine, 2018), teachers even need to be aware of the extent that previous learning experiences have been meaningful and connected to their lives. (Amy, 2018) teachers should establish a classroom expectation where all students are expected to participate and employ strategies to encourage participation of multiple voices in discussion. Teachers must design the lesson plans according to their students' needs. Teachers also have to use a variety of different pedagogy to increase their students' attention during the teaching and learning process.

\subsection{Advantages and Disadvantages of Culturally Responsive Pedagogy}

(Amy, 2018), culturally responsive pedagogy allows the positive classroom culture and enhanced inter-student and teacher-student relationships serve to boost student self-esteem and self-worth which results in increased confidence and sense of safety in the classroom. In a classroom where culturally responsive pedagogy is practiced, bridges are built that connect students, teachers, schools, 
and community.

Amy (2018), participants spoke at length about challenges that result when trying to navigate potentially controversial topics in the classroom, especially when the teacher may have limited background knowledge in relation to the given topic or may disagree with the practices of a group. Such topics can result in discomfort, and, as a result, may be minimized or avoided.

\section{Research Objective and Research Question}

There are many issues regarding the implementation of culturally responsive pedagogy. The purpose of this study is therefore to review several studies on the competent of teachers in implementation of culturally responsive pedagogy.

The research questions, therefore, are 1) Are the teachers competent in the implementation of culturally responsive pedagogy? 2) What hinders the implementation of culturally responsive pedagogy?

\section{Methodology}

During the selection process of the review article, two steps are used first in the Preferred Reporting Items for Systematic Reviews and Meta-Analyses (PRISMA) protocol (2009) and follow by the McDermott model (2014). By using PRISMA protocol, researcher was able to filter and only use those selected articles for systematic review. Besides, the McDermott model allows researchers to compare the components between the journals and articles found. The details are as follows:

\subsection{Preferred Reporting Items for Systematic Reviews and Meta-Analyses (PRISMA) Protocol (2009)}

PRISMA Protocol (2009) was suggested by Moher D, Liberati A, Tetzlaff J, Altman DG. Four steps are defined in the PRISMA protocol, such as identification, screening, eligibility and included.

\subsubsection{Identification}

The search process for finding articles that are related to culturally responsive pedagogy via Education Resource Information Center (ERIC), SAGE Journals, and EBSCOHOST Discovery reference databases at the identification stage through identification. There are three keywords used: culturally responsive pedagogy, competence of teachers, implementation of culturally responsive pedagogy. It refers to inclusive and exclusive criteria for obtaining the data that really fulfills the objectives of the study. The criteria used are inclusive and exclusive:

1) Use of the symbol “+, -, AND, culturally responsive pedagogy".

2) Limit the search year, searches are only based from 2010 to 2019 .

3) Search sources such as journals, proceedings or reports.

4) Use articles references to track other appropriate articles.

\subsubsection{Screening}

About 500 articles related to the culturally responsive pedagogy were found in the first results. The articles found were then filtered on the basis of: 
1) Priority to those articles related to culturally responsive pedagogy.

2) The article described the competence of teachers in implementation of culturally responsive pedagogy.

\subsubsection{Eligibility and Included}

Eligible data collection uses a variety of sources of data. Thus, articles from journals, theses, case study and action research are obtained. Through systematic review, only qualitative research articles are included and analyzed. The total item obtained from the PRISMA protocol is approximately 120 . The process of selecting the study using the PRISMA protocol is shown in Figure 1. In this systematic review, only 15 qualitative research articles which related to the topic are included and analyzed.

By using ERIC reference databases, total articles found $=2811$, after screening $=25$ (only 5 articles which meet the objectives selected to be analyzed). Via using SAGE reference databases, total articles found $=2500$, after screening $=40$ (only 7 articles which meet the objectives selected to be analyzed). Through EBSCOHOST Discovery reference databases, total articles found $=1500$, after screening $=20$ (only 3 articles which meet the objectives selected to be analyzed).

Some of the journals appear twice in different reference database, so the researcher just takes either one from the reference database.

\subsection{McDermott}

However, the process of selecting this article does not stop here but continues with the second filtering process using the McDermott model. Using the McDermott model, the research article obtained from the PRISMA protocol is filter again. The researcher adapted this model to view the quality of the selected articles based on the study's 6 quality assessment criteria. The current criteria for quality assessment are outlined in Table 1.

Articles that exceed the evaluation quality are also graded. Each article is graded whether A, B, C or D. Grading articles are made as follows: (Table 2).

After the research article's filtering process, only 15 articles are obtained that meet the study's goals and systematically reviewed. Then each selected article will be theme-based coding. The coding of the study was done using a combination of alphabets and numbers. "E" is represented as an element and "I" for issue. While the number $(1,2,3, \cdots)$ indicates of each criterion involve. This representation is used to facilitate the researcher to make analysis of the study data and to reveal the findings of a more systematic study (Table 3 ).

\section{Finding}

\subsection{Element}

There are three key elements related to culturally responsive pedagogy, taking into account the findings. The elements are teachers' knowledge, teachers' understanding and teachers' self-efficacy. Table 4 shows the element details. 


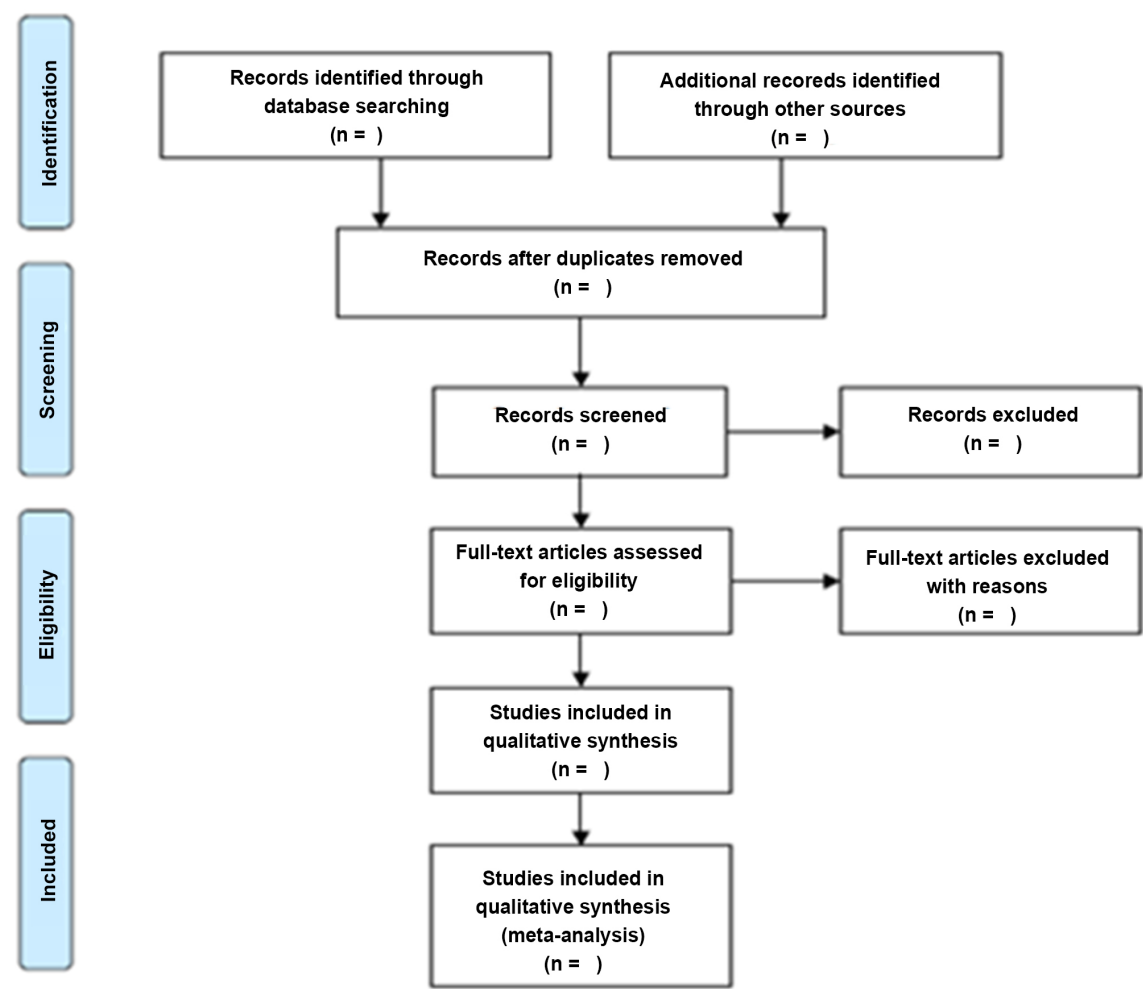

Figure 1. Data collection using PRISMA protocol.

Table 1. Filtering process by using McDermott (2004).

\begin{tabular}{|c|c|c|}
\hline No & Element & Descriptions \\
\hline 1 & Goals and objectives & Does the article clearly state the goals and objective? \\
\hline 2 & Study context & $\begin{array}{l}\text { Does the article explain clearly how the study involved } \\
\text { planning, implementation and development was conducted? }\end{array}$ \\
\hline 3 & Sample & Does the article provide a sufficient sample of research? \\
\hline 4 & Methodology & $\begin{array}{l}\text { Does the article provide a research methodology description } \\
\text { that includes frameworks for the study, data collection and } \\
\text { data analysis? }\end{array}$ \\
\hline 5 & Data & $\begin{array}{l}\text { Is support such as schedule, interview/focus and feedback } \\
\text { from observations included? } \\
\text { Is the information being clearly translated and analysed? }\end{array}$ \\
\hline 6 & $\begin{array}{l}\text { The results of the } \\
\text { study are validated }\end{array}$ & $\begin{array}{l}\text { Does the researcher verify the study's analysis by means of } \\
\text { expert review, feedback or other mechanisms? }\end{array}$ \\
\hline
\end{tabular}

The findings show that the key elements in culturally responsive pedagogy included teachers' knowledge, teachers' understanding and teachers' self-efficacy. $13(41 \%)$ articles reporting on teachers' knowledge about culturally responsive pedagogy, which means that most of the teachers know something about culturally responsive pedagogy. Peer learning and official training should be given for 
Table 2. Quality assessment of the rated articles based on Grading A, B, C and D.

\begin{tabular}{|c|c|c|c|c|c|c|c|c|}
\hline \multirow{2}{*}{ Researcher } & \multirow[b]{2}{*}{ Year } & \multicolumn{6}{|c|}{ Criteria } & \multirow[t]{2}{*}{ Grade } \\
\hline & & $\begin{array}{l}\text { Goals and } \\
\text { objectives }\end{array}$ & Study context & Sample & Methodology & Data & $\begin{array}{l}\text { The results of the } \\
\text { study are validated }\end{array}$ & \\
\hline Christian, D. & 2011 & I & I & I & I & I & I & A \\
\hline Susan, V. B. & 2012 & I & I & I & I & I & I & B \\
\hline Richard, H. M. & 2014 & I & I & I & I & I & I & A \\
\hline $\begin{array}{l}\text { Mayfield, V.M., } \\
\text { Garrison-Wade, D. }\end{array}$ & 2015 & I & I & I & I & I & I & A \\
\hline Lori, C. A., Minda Morren, L. & 2015 & I & I & I & l & I & I & B \\
\hline Michele, E. et al & 2016 & I & I & I & I & I & I & A \\
\hline Amy, J. S. et al. & 2017 & I & & I & I & I & I & B \\
\hline Thomas, A. L. et al. & 2017 & I & I & I & l & I & I & A \\
\hline Gerg, V. & 2017 & I & & I & I & I & I & B \\
\hline Patricia, J. B. et al. & 2017 & l & I & I & l & I & I & A \\
\hline Chezare, A. W. & 2018 & I & I & I & I & I & I & A \\
\hline Laura, K., Christine, A. & 2018 & I & I & I & I & I & I & A \\
\hline Thomas, M. & 2018 & I & I & I & I & I & I & A \\
\hline Amy, J. S. & 2018 & I & I & I & I & I & I & A \\
\hline Sylvia, L.-T., et al. & 2018 & l & I & l & l & I & I & A \\
\hline Grading of the article & \multicolumn{4}{|c|}{ Description } & & & & \\
\hline A & \multicolumn{4}{|c|}{ The six criteria were qualified } & & & & \\
\hline B & \multicolumn{4}{|c|}{ Approximately five designated criteria qualified } & & & & \\
\hline $\mathrm{C}$ & \multicolumn{4}{|c|}{ Four criteria qualified } & & & & \\
\hline $\mathrm{D}$ & \multicolumn{4}{|c|}{ Qualified with just three criteria } & & & & \\
\hline
\end{tabular}

teachers in order to increase their knowledge about culturally responsive pedagogy. Besides, 8 (25\%) articles reporting on teachers' understanding about culturally responsive pedagogy. This means there are still teachers who not really know the ways to implement culturally responsive pedagogy while teaching inside the class. On the other hand, 11 (34\%) articles reporting on teachers' self-efficacy using culturally responsive pedagogy. Teachers must find some ways to increase their knowledge about culturally responsive pedagogy.

\subsection{Issues}

Based on the results of the analysis, there are three issues that constitute the implementation of culturally responsive pedagogy, i.e. teacher pedagogy, curriculum and assessment.

\subsubsection{Teacher Pedagogy}

Students from different background and culture will need different pedagogy 
Table 3. Summary of include empirical article.

\begin{tabular}{|c|c|c|c|c|c|c|c|c|c|}
\hline \multirow{2}{*}{ Researcher } & \multirow{2}{*}{ Year } & \multirow{2}{*}{ Journal Title/Quartile } & \multicolumn{3}{|c|}{ Elements (E) } & \multicolumn{3}{|c|}{ Issues (I) } & \multirow[t]{2}{*}{ Findings } \\
\hline & & & E1 & E2 & E3 & I1 & I2 & I3 & \\
\hline Christian, D. & 2011 & $\begin{array}{l}\text { Qualifying Sociopolitical } \\
\text { Consciousness: } \\
\text { Complicating Culturally } \\
\text { Responsive } \\
\text { Pedagogy for Faith-Based } \\
\text { Schools }\end{array}$ & 1 & & l & I & 1 & I & $\begin{array}{l}\text { Teachers found that issues such as } \\
\text { immigration, racism, the political } \\
\text { process, and religious discrimination } \\
\text { caused the culture problem inside the } \\
\text { classroom. } \\
\text { - Catholic teachers have to adapt to the } \\
\text { situation while teaching in the church. }\end{array}$ \\
\hline Susan, V. B. & 2012 & $\begin{array}{l}\text { Effective Facets of a } \\
\text { Field Experience That } \\
\text { Contributed to Eight } \\
\text { Preservice Teachers' } \\
\text { Developing } \\
\text { Understandings } \\
\text { About Culturally } \\
\text { Responsive Teaching }\end{array}$ & / & & l & 1 & l & I & $\begin{array}{l}\text { preservice teachers' effective and } \\
\text { ineffective facets of field experience } \\
\text { affect their ability to develop their } \\
\text { understandings of culturally } \\
\text { responsive teaching } \\
\text { - preservice teachers have to get full } \\
\text { understanding of culturally responsive } \\
\text { pedagogy to increase self-efficacy. }\end{array}$ \\
\hline Richard, H. M. & 2014 & $\begin{array}{l}\text { Culturally Relevant, } \\
\text { Purpose-Driven } \\
\text { Learning \& Teaching } \\
\text { in a Middle School Social } \\
\text { Studies Classroom }\end{array}$ & I & 1 & l & & I & I & $\begin{array}{l}\text { teachers need to be prepared to do } \\
\text { more than teach subject matter such as } \\
\text { science, language arts, social studies, } \\
\text { and mathematics. }\end{array}$ \\
\hline $\begin{array}{c}\text { Lori, C. A., \& } \\
\text { Minda Morren, L. }\end{array}$ & 2015 & $\begin{array}{l}\text { Generative Learning in a } \\
\text { Service-Learning Project and } \\
\text { Field-Base Teacher Education } \\
\text { Program: Learning to Become } \\
\text { Culturally Responsive } \\
\text { Teachers }\end{array}$ & l & & l & & I & I & $\begin{array}{l}\text { through CRP teacher education } \\
\text { program, teachers prespective for CRP } \\
\text { turn from fearful to excited, from } \\
\text { inexperienced to confident. } \\
\text { - this changes is due to students' success } \\
\text { in learning via CRP. }\end{array}$ \\
\hline $\begin{array}{c}\text { Mayfield, V.M. \& } \\
\text { Garrison-Wade, D. }\end{array}$ & 2015 & $\begin{array}{l}\text { Culturally responsive } \\
\text { practices as whole school } \\
\text { reform }\end{array}$ & / & & I & 1 & 1 & I & $\begin{array}{l}\text { cultural competency of staff must be } \\
\text { built so that a professional } \\
\text { development in education can be seen. }\end{array}$ \\
\hline Michele, E., et al. & 2016 & $\begin{array}{l}\text { Culturally Responsive } \\
\text { Teaching: Examining } \\
\text { Teachers' Understandin-gs } \\
\text { and Perspectives }\end{array}$ & & 1 & I & I & I & I & $\begin{array}{l}\text { Only a number of teachers include } \\
\text { culture within their curriculum. } \\
\text { - some of the teachers found that } \\
\text { culturally responsive teaching is } \\
\text { challenging. }\end{array}$ \\
\hline Patricia, J. B., et al. & 2017 & $\begin{array}{l}\text { Voices From Urban } \\
\text { Classrooms: Teachers' } \\
\text { Perceptions on } \\
\text { Instructing Diverse } \\
\text { Students and Using } \\
\text { Culturally Responsive } \\
\text { Teaching }\end{array}$ & l & / & & 1 & 1 & & $\begin{array}{l}\text { Students should be given equitable } \\
\text { treatment for their weakness, respect } \\
\text { and high expectations inside the } \\
\text { classroom. } \\
\text { - Teachers should not show any racist } \\
\text { towards the students. }\end{array}$ \\
\hline \multirow{2}{*}{ Researcher } & \multirow{2}{*}{ Year } & & \multicolumn{3}{|c|}{ Elements (E) } & \multicolumn{3}{|c|}{ Issues (I) } & Findings \\
\hline & & & E1 & $\mathrm{E} 2$ & E3 & I1 & $\mathrm{I} 2$ & $\mathrm{I} 3$ & \\
\hline Thomas A. L., et al. & 2017 & $\begin{array}{l}\text { Mentorship in Higher } \\
\text { Education } \\
\text { Compassionate Approaches } \\
\text { Supporting } \\
\text { Culturally Responsive } \\
\text { Pedagogy }\end{array}$ & 1 & & l & / & I & I & $\begin{array}{l}\text { - students' experiences are entirely } \\
\text { based on the mentee's perceptions } \\
\text { the patterns of communication } \\
\text { between the two participants are based } \\
\text { on their personal experiences and } \\
\text { histories }\end{array}$ \\
\hline
\end{tabular}




\section{Continued}

\begin{tabular}{|c|c|c|c|c|c|c|c|c|c|}
\hline Amy, J. S., et al. & 2017 & $\begin{array}{l}\text { Examining Perceptions of } \\
\text { Culturally Responsive } \\
\text { Pedagogy in Teacher } \\
\text { Preparation and Teacher } \\
\text { Leadership Candidates }\end{array}$ & 1 & & 1 & 1 & 1 & & $\begin{array}{l}\text { low awareness of the cultural } \\
\text { implications for positive educational } \\
\text { experiences }\end{array}$ \\
\hline Greg, V. & 2017 & $\begin{array}{l}\text { Preparing for Culturally } \\
\text { Responsive } \\
\text { Schooling: Initial Teacher } \\
\text { Educators } \\
\text { Into the Fray }\end{array}$ & 1 & I & & I & I & & $\begin{array}{l}\text { interconnections between teacher } \\
\text { education, school leadership, and } \\
\text { inservice professional development is } \\
\text { important to make sure that culturally } \\
\text { responsive pedagogy do work properly }\end{array}$ \\
\hline Amy, J. S. & 2018 & $\begin{array}{l}\text { Exploring Culturally } \\
\text { Responsive Pedagogy: } \\
\text { Teachers' Perspectives on } \\
\text { Fostering Equitable and } \\
\text { Inclusive Classrooms }\end{array}$ & 1 & I & & 1 & I & & $\begin{array}{l}\text { barriers to facilitating a culturally } \\
\text { responsive pedagogy, approaches and } \\
\text { pedagogical tools for fostering equita- } \\
\text { ble and inclusive classrooms. }\end{array}$ \\
\hline Chezare, A. W. & 2018 & $\begin{array}{l}\text { Empathy, Teacher } \\
\text { Dispositions, and Preparation } \\
\text { for Culturally } \\
\text { Responsive Pedagogy }\end{array}$ & 1 & I & & I & 1 & & $\begin{array}{l}\text { teachers should be able to produce } \\
\text { evidence of culturally responsive } \\
\text { pedagogy in their future teaching. }\end{array}$ \\
\hline $\begin{array}{l}\text { Laura, K. and } \\
\text { Christine, A. }\end{array}$ & 2018 & $\begin{array}{l}\text { Connecting Universal } \\
\text { Design for Learning } \\
\text { With Culturally } \\
\text { Responsive Teaching }\end{array}$ & 1 & I & 1 & 1 & I & 1 & $\begin{array}{l}\text { - teachers must point out how students' } \\
\text { differences affect learning and align } \\
\text { pedagogies inside the classroom. }\end{array}$ \\
\hline Thomas, M. & 2018 & $\begin{array}{l}\text { Culturally Responsive } \\
\text { Curriculum and Pedagogy in } \\
\text { the Common wealth of the } \\
\text { Northern Mariana Island }\end{array}$ & 1 & & 1 & 1 & 1 & 1 & $\begin{array}{l}\text { the efforts to promote cultural } \\
\text { responsiveness largely hinged on } \\
\text { creating meaningful connections for } \\
\text { students }\end{array}$ \\
\hline $\begin{array}{l}\text { Sylvia, } \\
\text { L.-T., et al. }\end{array}$ & 2018 & $\begin{array}{l}\text { Exploring the Intersection of } \\
\text { Evidence-Based Practices } \\
\text { and Culturally and } \\
\text { Linguistically Responsive } \\
\text { Practices }\end{array}$ & & I & 1 & I & 1 & & $\begin{array}{l}\text { teachers have to always make sure that } \\
\text { their lesson plans involving the use of } \\
\text { culturally responsive pedagogy which } \\
\text { suit their students. }\end{array}$ \\
\hline
\end{tabular}

Guideline of the summary table, E1: Teachers' knowledge, E2: Teachers' understanding, E3: Teachers' self-efficacy; I1: Teacher pedagogy, I2: Curriculum, I3: Assessment.

Table 4. Report number of articles based on elements.

\begin{tabular}{ccc}
\hline Elements & Report number of articles & Percentage \\
\hline Teachers' knowledge & 13 & $41 \%$ \\
Teachers' understanding & 8 & $25 \%$ \\
Teachers' self-efficacy & 11 & $34 \%$ \\
\hline
\end{tabular}

used by the teachers. Culturally responsive pedagogy training courses is given to train those teachers who still not mastering in culturally responsive pedagogy. From the systematic review, there are still a number of teachers who do not really know the way to use culturally responsive pedagogy. There are still some of 
the teachers found out that this pedagogy is difficult to apply inside the class. Moreover, preservice teachers are also lack of ideas on how culturally responsive pedagogy is going function. We can figure out clearly that demonstration and practices is carry out continuously so that all the teachers know the way to apply culturally responsive pedagogy. Ainun et al. (2017), most of the students enjoy learning Malay language for the teaching pedagogy from their teacher actually help them to develop their interests in learning Malay language.

\subsubsection{Curriculum}

From the systematic literature review, we can find that teachers' curriculum got $15(22 \%)$ reports recorded. Only some of the teachers master in the field they are teaching. Culturally responsive pedagogy affects the teaching skill of teachers who have to teach students from different culture background. Besides that, the curriculum designed by the government has guidelines for teachers. A step-by-step approach sure will be helpful for teachers. It will be better if a few learning activities is suggested inside the guidelines. Moreover, the curriculum designed must be appropriate to the cultural background of the students. Zamri et al. (2016), teachers need to be aware of the problems that students face and immediately help them to avoid missing out on lessons. On the other words, teachers need to master not only the curriculum but also to be culturally aware of the students' background which may help students to learn better.

\subsubsection{Assessment}

The assessment designed by the teachers shall have appropriate to the cultural background of the students too. Teachers shall have to avoid sensitive issues inside the assessment. The level of assessment shall not be too tough or too easy for the students too. Students would be demotivated if they always get low marks for the assessment given. Standard questions shall be included 30\% of easy questions, $50 \%$ of normal question and lastly $20 \%$ of tough questions. Through assessment given by the teachers, students can get to know how many percentage of knowledge they have learnt inside the culturally responsive pedagogy.

\subsection{Year of Report}

It is found that in the light of the report year, teacher is the key element contributing to the implementation of culturally responsive pedagogy. Researcher reported 32/69 teacher-related issues from year 2010 to 2019 with a total of $46 \%$. Table 5 shows the year of reported issues based on elements (Graph 1).

\section{Researcher Reports}

There are 60 issues reported by 18 researchers in the implementation of culturally responsive pedagogy from 2010 to 2019 . Table 5 shows the number of reported problems.

\section{Discussion and Conclusion}

The result shows that teachers' knowledge, teachers' understanding and teachers' 
Table 5. Year of reported issues based on elements.

\begin{tabular}{|c|c|c|c|c|c|c|c|c|c|}
\hline \multirow{2}{*}{ Elements } & \multicolumn{8}{|c|}{ Year of Report } & \multirow{2}{*}{ Total (\%) } \\
\hline & 2011 & 2012 & 2013 & 2014 & 2015 & 2016 & 2017 & 2018 & \\
\hline $\begin{array}{c}\text { Teacher } \\
\text { knowledge }\end{array}$ & 1 & 1 & & 1 & 2 & & 4 & 4 & $13(19 \%)$ \\
\hline $\begin{array}{c}\text { Teacher } \\
\text { understanding }\end{array}$ & & & & 1 & & 1 & 2 & 4 & $8(11 \%)$ \\
\hline $\begin{array}{c}\text { Teacher } \\
\text { self-efficacy }\end{array}$ & 1 & 1 & & 1 & 2 & 1 & 2 & 3 & $11(16 \%)$ \\
\hline Pedagogy & 1 & 1 & & & 1 & 1 & 4 & 5 & $13(19 \%)$ \\
\hline Curriculum & 1 & 1 & & 1 & 2 & 1 & 4 & 5 & $15(22 \%)$ \\
\hline Assessment & 1 & 1 & & 1 & 2 & 1 & 1 & 2 & $9(13 \%)$ \\
\hline Total & 5 & 5 & & 5 & 9 & 5 & 17 & 23 & $69(100 \%)$ \\
\hline
\end{tabular}

Elements and issues based Annual Report Graphs

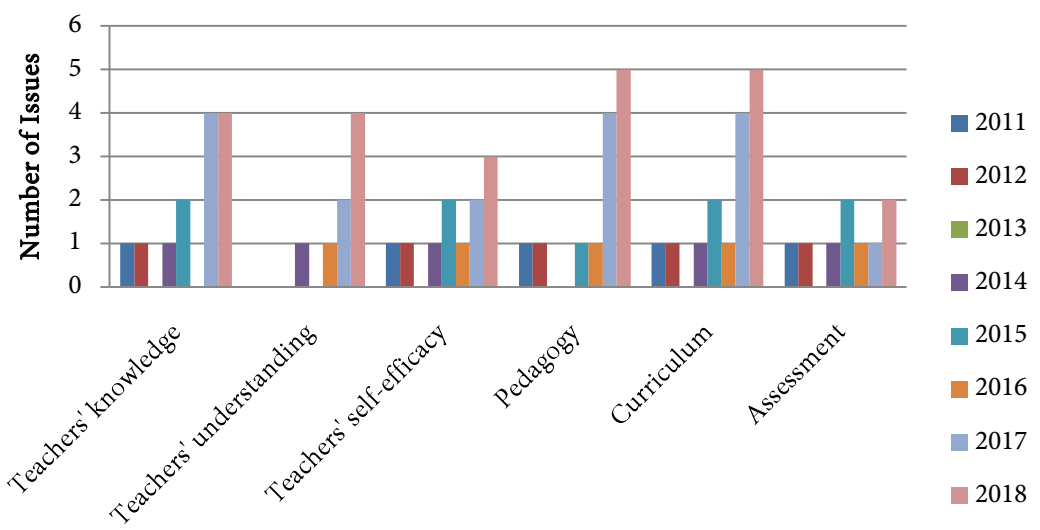

Elements

Graph 1. Elements and issues based annual report graphs.

self-efficacy are the elements for competence of teachers in implementation of culturally responsive pedagogy. On the other hand, pedagogy, curriculum and assessment are the issues in implementation of culturally responsive pedagogy. This result is closely related to teachers' practice in culturally responsive pedagogy. Gay (2010) defines it as teaching "to and through students' personal and cultural strengths, their intellectual capabilities, and their prior accomplishments" (p. 26).

Teachers should be given more training on the way to implement culturally responsive pedagogy in teaching as to make sure all the students with different cultural background learn something. Gutiérrez (2002) argues that rather than basing pedagogy and curriculum on global and stereotypic racial and language identities that others project onto the students, excellent teachers take the time to get to know their students, then shape their pedagogy around relationships with them. When the cultures of students and teachers are not synchronized, someone loses out (Christian, 2011). 
Hasnah et al. (2017), research result shows that teacher have to provide opportunities for students to provide their opinion inside the classroom, even encouraging students think and act creatively. By using this way, students' confidence in learning can be increased. Ong, et al. (2013), students of different levels of emotional intelligence will be able to motivate himself to deal with low levels of emotional intelligence in the process of learning. By using culturally responsive pedagogy, students of different levels of emotional intelligence will show improvement in their studies, as they can feel their teachers' concern while learning inside the class.

On the other hand, several problems have been identified as an obstacle in implement culturally responsive pedagogy. Case studies of teachers learning culturally responsive pedagogy illuminate problems and barriers teachers experience, sometimes showing how those problems can be addressed (e.g., Bondy, Ross, Gallingane, \& Hambacher, 2007; Milner, 2010; Patchen \& Cox-Petersen, 2008; Sleeter, 2005).

Khairul et al. (2017), students' motivation involves attitude towards learning Malay, the desire to learn the Language Malay, as well as instrumental motivation. Components of instrumental motivation shows high level of motivation and significant. High level of students in learning Malay Language will increase their desire in learning the language.

\section{Conclusion}

As a conclusion, teachers have to master culturally responsive pedagogy in order to make full use of this pedagogy. Moreover, the government should make effort by having culturally responsive pedagogy training for teachers. By this, teachers will be able to master and able to carry out the pedagogy.

\section{Acknowledgements}

This research is supported by Universiti Kebangsaan Malaysia under research "Dana Penyelidikan FPend" scheme no. PP-FPEND-2019.

\section{Conflicts of Interest}

The authors declare no conflicts of interest regarding the publication of this paper.

\section{References}

Ainun Rahman, I., Zamri, M., \& Wan Muna Ruzanna, W. M. (2017). Pembelajaran Abad ke-21 dan Pengaruhnya terhadap Sikap, Motivasi dan Pencapaian Bahasa Melayu Pelajar Sekolah Menengah. Jurnal Pendidikan Bahasa Melayu, 7, 77-88.

Amy, J. S. (2018). Exploring Culturally Responsive Pedagogy: Teachers' Perspectives on Fostering Equitable and Inclusive Classrooms. SRATE Journal Winter, 27, 22-30.

Amy, J. S., Gregory, L. S., \& Tammy, M. C. (2017). Examining Perceptions of Culturally Responsive Pedagogy in Teacher Preparation and Teacher Leadership Candidates. 
SRATE Journal Summer, 26, 50-60.

Bondy, E., Ross, D. D., Gallingane, C., \& Hambacher, E. (2007). Creating Environments of Success and Resilience. Urban Education, 42, 326-348. https://doi.org/10.1177/0042085907303406

Chezare, A. W. (2018). Empathy, Teacher Dispositions, and Preparation for Culturally Responsive Pedagogy. Journal of Teacher Education, 69, 169-183. https://doi.org/10.1177/0022487117712487

Christian, D. (2011). Qualifying Sociopolitical Consciousness: Complicating Culturally Responsive Pedagogy for Faith-Based Schools. Education and Urban Society, 45, 266-284. https://doi.org/10.1177/0013124511408597

Gay, G. (2010). Culturally Responsive Teaching (2nd ed.). New York: Teachers College Press.

Greg, V. (2017). Preparing for Culturally Responsive Schooling: Initial Teacher Educators into the Fray. Journal of Teacher Education, 68, 451-462.

https://doi.org/10.1177/0022487117702578

Hasnah, I., \& Jamaludin, B. (2017). Kompetensi Guru Bahasa Melayu dalam Menerapkan Kemahiran Berfikir Aras Tinggi dalam Pengajaran dan Pembelajaran. Jurnal Pendidikan Bahasa Melayu, 7, 56-65.

Khairul Nizam, M. Z., \& Wan Muna Ruzanna, W. M. (2017). Sikap dan Motivasi Murid Bajau dalam Mempelajari Bahasa Melayu Sebagai Bahasa Kedua. Jurnal Pendidikan Bahasa Melayu, 7, 24-33.

Ladson-Billings, G. (1995). But That's Just Good Teaching! The Case for Culturally Relevant Pedagogy. Theory into Practice, 34, 159-165. https://doi.org/10.1080/00405849509543675

Laura, K., \& Christine, A. (2018). Connecting Universal Design for Learning with Culturally Responsive Teaching. Education and Urban Society, 51, 1202-1216.

Lori, C. A., \& Minda Morren, L. (2015). Generative Learning in a Service-Learning Project and Field-Base Teacher Education Program: Learning to Become Culturally Responsive Teachers. Literacy Research: Theory, Method, and Practice, 64, 323-338. https://doi.org/10.1177/2381336915617578

Mayfield, V. M., \& Garrison-Wade, D. (2015). Culturally Responsive Practices as Whole School Reform. Journal of Instructional Pedagogies, 16, 1-17.

Michele, E., Huihui, K. M., \& Alice, K. (2016). Culturally Responsive Teaching: Examining Teachers' Understandings and Perspectives. Journal of Education and Training Studies, 4, 97-104. https://doi.org/10.11114/jets.v4i2.1136

Milner, H. R. (2010). Start Where You Are, But Don't Stay There: Understanding Diversity, Opportunity Gaps, and Teaching in Today's Classrooms. Cambridge, MA: Harvard Education Press.

Milner, H. R. (2011). Culturally Relevant Pedagogy in a Diverse Urban Classroom. Urban Review, 43, 66-89. https://doi.org/10.1007/s11256-009-0143-0

Ong, S. C., Zamri, M., \& Hamidah, Y. (2013). Faktor Jantina, Kaum, Aliran Kelas dan Hubungnya dengan Kecerdasan Emosi Murid dalam Mempelajari Bahasa Melayu. Jurnal Pendidikan Bahasa Melayu, 3, 12-23.

Patchen, T., \& Cox-Petersen, A. (2008). Constructing Cultural Relevance in Science: A Case Study of Two Elementary Teachers. Science Education, 92, 994-1014.

Patricia, J. B., Susan, R. W., \& Ying, H. J. (2017). Voices From Urban Classrooms: Teachers' Perceptions on Instructing Diverse Students and Using Culturally Responsive Teaching. Education and Urban Society, 50, 697-726. 
https://doi.org/10.1177/0013124517713820

Richard, H. M. (2014). Culturally Relevant, Purpose-Driven Learning \& Teaching in a Middle School Social Studies Classroom. Multicultural Education, 21, 9-17.

Sleeter, C. E. (2005). Multicultural Teaching in Standards-Based Classrooms. New York: Teachers College Press.

Susan, V. B. (2012). Effective Facets of a Field Experience That Contributed to Eight Preservice Teachers' Developing Understandings about Culturally Responsive Teaching. Urban Education, 48, 380-419. https://doi.org/10.1177/0042085912452155

Sylvia, L. T., Julie, A. L. M., \& Linda, O. C. (2018). Exploring the Intersection of Evidence-Based Practices and Culturally and Linguistically Responsive Practices. Intervention in School and Clinic, 54, 6-13. https://doi.org/10.1177/1053451218762574

Thomas, A. L., \& Elizabeth, S. W. (2017). Mentorship in Higher Education. Compassionate Approaches Supporting Culturally Responsive Pedagogy. Multicultural Education, 24, 11-17.

Thomas, M. (2018). Culturally Responsive Curriculum and Pedagogy in the Commonwealth of the Northern Mariana Islands. International Journal of Multicultural Education, 20, 81-100. https://doi.org/10.18251/ijme.v20i2.1575

Zamri, M., Kamulliah, A. G., \& Wan Muna Ruzanna, W. M. (2016). Penggunaan Strategi Pembelajaran Bahasa Melayu dalam Kalangan Murid Cina Berdasarkan Sikap dan Kemahiran Bahasa. Jurnal Pendidikan Bahasa Melayu, 6, 38-51. 